\title{
CYP2D6*19 Allele
}

National Cancer Institute

\section{Source}

National Cancer Institute. CYP2D6*19 Allele. NCI Thesaurus. Code C46051.

Human CYP2D6*19 allele is located in the vicinity of $22 \mathrm{q} 13.1$ and is approximately $4 \mathrm{~kb}$ in length. This allele, a variant form of the CYP2D6 wild-type allele, encodes cytochrome P450 2D6*19 protein. The CYP2D6*19 allele exhibits a four nucleotide deletion (g.2539delAACT) that results in a frameshift during protein coding. This alteration abolishes the enzymatic activity of the cytochrome P450 2D6*19 protein. 